\title{
EVALUASI PEMIKIRAN QASIM AMIN TENTANG EMANSIPASI WANITA DALAM ISLAM
}

\author{
Achmad Tohari', Dian Pramodya Cahyani² \\ 1,2UIN Sunan Ampel Surabaya
}

\begin{abstract}
ABSTRAK
Gagasan emansipasi wanita adalah sebagai perwujudan atas pedulinya Qasim Amin mengenai realitas wanita Mesir yang masih jauh di bawah dominasi laki-laki. Penelitian pustaka ini berupaya menganalisis pemikiran Qasim Amin - yang juga merupakan tokoh reformasi Mesir - dalam sudut pandang lebih luas dengan sumber-sumber yang relevan. Selanjutnya penulis mengevaluasi pemikirannya dalam bingkai pendidikan Islam modern. Penelitian ini menemukan bahwa, menurut Qasim Amin, wanita Mesir bukan lagi mengenai hubungan nya dengan laki-laki, namun juga mengenai sosiologis dan hak merdeka sebagai individu sudah tersangkut paut pada keyakinan tradisional serta praktek patriaki yang mengatasnamakan agama terbilang sudah mapan. Dari pemikiran Qasim Amin inilah akan diarahkan kepada masalah wanita di dunia pendidikan yang saat ini terjadi, yang mana wanita sudah termasuk atau bisa membuat perubahan terhadap zaman. Dalam konteks pendidikan Islam, pemikiran Qasim Amin dapat mengembangkan berpikir demokratis dengan membentuk akhlakul karimah yang sesuai kemampuan akal dan konteks kemanusiaan secara universal.

Kata Kunci: Qasim Amin, Emansipasi Wanita, Gender, Pendidikan Islam.

\section{ABSTRACT}

The idea of women's emancipation is a manifestation of Qasim Amin's concern about the reality of Egyptian women who are still far under the domination of men. This literature research attempts to analyze the thoughts of Qasim Amin - who is also an Egyptian reformer - in a broader perspective with relevant sources. Furthermore, the author evaluates his thoughts in the frame of modern Islamic education. This research finds that according to Qasim Amin, Egyptian women are no longer about their relationship with men, but also about sociological and independent rights as individuals who are already tied to traditional beliefs and patriarchal practices in the name of religion are fairly well established. From the thoughts of Qasim Amin, it will be directed to the problem of women in the world of education that is currently happening, where women are included or can make changes to the times. In the context of Islamic education, Qasim Amin's thoughts can develop democratic thinking by forming akhlaq al-karimah that is in accordance with the ability of reason and the context of universal humanity.

Keywords: Qasim Amin, Women's Emancipation, Gender, Islamic Education.
\end{abstract}

\section{A. Pendahuluan}

Dalam sejarah kebudayaan Islam setelah wafatnya Nabi, kekuasaan yang dimiliki umat Islam mengalami peluasan hingga pada bekas penjajahan Persia dan Romawi yang pembentangannya mulai dari Spanyol hingga ke Benua India. ${ }^{1}$ Dalam budaya masyarakat saat itu di wilayah tersebut dipengaruhi oleh budaya patriarchal yang mana menganggap wanita sebagai the second sex. Cara pandang dan pembahasan para Tokoh dalam melihat situasi tersebut tidaklah menjadi kesulitan ketika menjelaskan bahwasanya keadaan masyarakatnya disana memang masih menganut atau terpengaruh oleh sebuah tradisi dan budaya lokalnya terutama kaitanya dengan hubungan laki-laki

\footnotetext{
${ }^{1}$ Christine Schirrmacher, Islam and Society, ed. by Geoff Tunnicliffe (Bonn: Verlag für Kultur und Wissenschaft, 2008).
} 
dan wanita. ${ }^{2}$ Hal inilah yang membuat mengapa wanita pada masa tersebut mengalami keburukan. Sebab, bukan semakin membaik ketika di tinggal pasca wafatnya Nabi, namun semakin menjauh dari kondisi yang terlihat seimbang. Tidak hanya sampai disitu namun Islam dipakai sebagai suatu variable dalam pembentukan akan kesadaran sosial atas berbagai persoalan tradisi yang ada di masyarakat. ${ }^{3}$

Pada abad ke-19 M kemajuan ilmu dan teknologi modern memasuki dunia Islam dengan sejarah didalamnya sebagai pandangan permulaan periode modern. Pada periode ini bisa disebut sebagai awal akan bangkitnya Islam. ${ }^{4}$ pada masa itulah mulai banyak para Tokoh Muslim mengkaji penyebab banyaknya umat Islam dari barat terutama wanita yang tidak terdidik dalam segi pendidikan. Banyak Tokoh mengkaji serta menyusun konsep akan gerakan pembaharuan atau sering disebut tajdid yang merupakan gerakan pembaharuan di dalam dunia Islam dengan proyek besarnya mengenai emansipasi wanita. ${ }^{5}$ Tajdid jika melihat dengan cara etimologinya berasal dari bahasa Arab “jaddada al-wudu'i” yang bisa diartikan sebagai memperbarui wudhu kemudian "jaddada al-ahda" yakni memperbaharui janji. Sehingga bisa di artikan bahwa pertama, suatu yang sedang diperbaharui tersebut sudah ada permulaanya kemudian bisa dikenal orang banyak, kedua, sesuatu tersebut telah berlalu beberapa waktu yang kemudian bisa rusak ataupun using, ketiga ialah sesuatu yang telah dikembalikan kepada manusia dengan keadaan semula seblum terjadi kerusakan. Dari situlah awal di mana persolan emansipasi wanita muncul dengan maksud menghilangkan deskriminatif terhadap kaum wanita yang mana sudah ada sejak dahulu. kemunculan mengenai emansipasi tidak bisa dipungkiri dari sikap dan pengaruh masyarakat Mesir pada saat itu yang menganggap wanita sebagai budak dan hanya untuk memuaskan nafsu. Yang membuat wanita tidak diperbolehkan ikut andil dalam dunia kelembagaan didunia pendidikan. ${ }^{6}$ Jika melihat pandangan dalam ajaran Islam, bahwa kodrat atau takdir antara kaum pria dengan kaum wanita sudah mempunyai tabiats secara berbeda sejak lahir, namun tidak sampai disitu bahwa kaum wanita juga

\footnotetext{
2 Siti Musdah Mulia, Muslimah Reformis: Perempuan Pembaru Keagamaan (Bandung: Mizan Pustaka, 2005$), 44$.

${ }^{3}$ Lihat, Ibn Hazm, Jawâmi' Sîrah Nabawiyyah (Beirut: Dar al-Kutub, t.t). Lihat pula, Sa'id Ramadhan Al-Buthi, Fiqh al-Sîrah (Damascus: Dar al-Fikr, 2008)

${ }^{4}$ Harun Nasution, Pembaharuab dalam Islam, Sejarah Pemikiran dan Gerakan (Jakarta: Bulan Bintang, 1975), 13.

${ }^{5}$ Masruroh, “Pemikiran Qasim Amin Tentang Hijab”, Jurnal Keislaman, Kemasyarakatan dan Kebudayaan, Vol. 18 No.1 (2017): 94.

6 Lihat, M. Zikwan, Emansipasi Wanita Menurut Qasim Amin (Media Akademika, 2011). Lihat juga, Eliana Siregar, "Pemikiran Qasim Amin Tentang Emansipasi Wanita”, Jurnal Ilmiah Kajian Gender, Vol.VI No. 2 (2016).
} 
memiliki kedudukan yang sama dalam perspektif kemanusiaan, sesuai dengan tafsiran ayat 1 QS Al-Nisa oleh Muhammad Ali Al-Shabuni:

"Bahwasanya manusia diciptakan jiwa atau orang yang atu yakni Adam dan saudaranya Hawa, dengan begitu bahwa sejatinya seluruh manusia secara kemanusiaan bersaudara sebab berasal dari satu orang ayah yang sama, sehingga harus saling menolong diantara keduanya yakni laki-laki dan perempuan,..."7

Melihat dari penafsiran diatas bisa dikatakan bahwa antara laki-laki dengan perempuan mempunyai keduudkan yang seimbang dalam sisi kemanusiaan dan antara keduanya bisa saling bekerja sama dalam segala hal. Dengan begitu perempuan dalam Islam tidak lagi dianggap sebagai yang terlemah, namun mempunyai kedudukan yang terhormat serta tidak kurang derajatnya dari pria. ${ }^{8}$ Ayat Al-Qur'an yang menegaskan bahwa ada kesejajaran mengenai wanita dengan laki-laki yakni pada QS. Al-Lail: 3-10, yang mana menyebutkan bahwa laki-laki dengan perempuan dalam qasam atau sumpah yang merupakan bukti bahwa Allah melihat persamaan diantara keduanya. Dari maksud kalimat tersebut bisa diartikan bahwa sebenarnya perbedaan manusia terletak pada aksinya yang mana melakukan kebaikan atau keburukan sehingga bisa diukur dari baik buruknya seseorang melalui aksi yang dilakukan oleh laki-laki maupun wanita. Dalam ayat tersebut merupakan pernafsiran Al-Qur'an terhadap prinsip taklif baik laki-laki ataupun perempuan mengenai problem dunia dan agama. ${ }^{9}$

Dalam pembahasaan bahasa Arab kata "Wanita" diterjemahkan dengan sebuah kata "an-nisa" yang mana mempunyai bentuk jama' dari kata "Mar'ah" merupakan perempuan yang sudah dewasa. Jika dalam kamus Besar Bahasa Indonesia bahwa wanita bisa diartikan sebagai perempuan yang pada dasarnya dewasa. Wanita sendiri ialah sebutan untuk homo sapiens berjenis kelamin betina. Menurut Damardjati ia mengungkapkan bahwa dalam kata "wanita" berasal dari kata wani (pemberani) dan tanpa (menderita) yang mana menurutnya bahwa wanita merupakan sosok yang berani menderita hanya dan bahkan untuk orang lain, sebab menurutnya bahwa wanita dikatakan seperti itu dengan melihat dalam kehidupan keseharian yang dilakukan wanita. ${ }^{10}$ Dari segi pendidikan wanita juga sering belum bisa bersaing dengan laki-laki, menurut Qasim Amin dari Bukunya mengenai Emansipasi wanita beranggapan jika wanita harus bisa disejajarkan dengan pria sehingga tidak timbul ketidak adilan.

\footnotetext{
${ }^{7}$ Muhammad Ali Shabuni, Shafwah al-Tafâsîr, Jilid 3 (Kairo: Darus Shabuni: 2009).

8 Ibid.

9 Su'ad Ibrahim Shalih, “Kedudukan Perempuan dalam Islam”, dalam Mohammad Atho Mudzhar dkk. Perempuan" dalam Masyarakat Indonesia: Akses, Pemberdayaan dan Kesempatan (Yogyakarta: Sunan Kalijaga Press, 2001), 40.

${ }^{10}$ Chrisna S. Handayani dan Ardhian Novianto, Kuasa Wanita Jawa (Yogyakarta: LKiS, Cet I, 2004), 24.
} 
Dalam analisanya terhadap kehidupan sosial yang mengenai hak wanita Mesir ternyata menurut Qasim bahwa wanita masih dalam keadaan tertinggal yang mana masih ada akan ikatan tradisi yang menutupinya yang bisa membuat tidak adanya kemajuan. la menginginkan agar wanita dengan laki-laki mempunyai hak yang relatif disamakan, sehingga akan adanya perubahan pada hal tersebut.

\section{B. Qasim Amin dan Gagasan Emansipasinya}

Dalam dunia Islam ada Tokoh yang sering dijadikan rujukan dalam melihat perkembangan wanita dalam pendidikan, namanya Qasim Amin seorang pemikir dari dunia Islam yang juga merupakan seorang pahlawan sekaligus nasionalis dalam Islam. ia juga seorang sastrawan yang sering mengkhayati sebuah makna keindahan di alam semesta serta juga musik dan kesenian yang lainnya. Qasim juga seorang pembaharu Muslim Mesir yang lahir di Pinggiran Kota Kairo pada tahun 1277 H/1861 M. Qasim merupakan anak dari seorang Ayah anggota tentara Iraq yang dipindahkan ke Mesir. la juga merupakan lulusan dari sekolah di Arab dan Perancis, setelah sekian lama ia di Perancis dan menyaksikan setiap warga negara baik pria maupun wanita memiliki kesempatan yang sejajar dengan laki-laki untuk ikut ambil bagian dalam berbagai lapangan kehidupan. berbalik arah dengan wanita yang mana terbelenggu dalam kebodohan dan keterbelakangan. ${ }^{11}$ Inilah yang membuat ia termotivasi akan dirinya sendiri sebagai hal untuk memperbaiki nasib kaum wanita melali pemikiran pembaharuannya yang mana dalam pemikirannya ia ingin menggabungkan yang dianggap baik antara budaya Arab dan budaya Perancis dengan merujuk kepada ajran Islam yakni al-Qur'an dan Hadith.

Qasim Amin dalam masa hidupnya terkenal dengan buku yang berjudul Tahrir al-Mar'ah yang menginginkan penghapusan dalam hal "adat hijab" yang mana bertentangan degan hakikat sebuah hijab dalam ajaran Islam. Qasim menginginkan agar wanita Mesir mendapat pendidikan serta pengajaran dengan dukungan secara layak dan bisa sejajar dengan laki-laki, ia juga menuntut akan perubahan dari praktek poligami dan perceraian yang mana ia anggap banyak tidak menguntungkan wanita Mesir. ${ }^{12}$

Dalam idenya mengenai pemikiran terhadap wanita, mempunyai tempat khusus dalam bidang kajian hak wanita sebagai manusia yang bisa berpendidikan dan bersaing dengan laki-laki. Sebab pengaruh wanita dalam Islam sangat diperhitungkan yang mana

\footnotetext{
${ }^{11}$ Masruroh, Pemikiran Qasim Amin Tentang Hijab, 93.

12 E. Erasiah, "Tokoh emansipasi wanita Islam di Mesir pada abad ke 19 M", Kafaah: Journal of Gender Studies, Vol.4 No.2 (2014): 202-218.
} 
wanita menjadi partner hidup untuk kaum pria yang tidak harus menjadi pelampias nafsu semata namun juga bisa setara dengan pria dalam bidang pendidikan maupu sosial. Dalam pemikiran dari Qasim menganggap bahwa banyak ketertingalan dalam menyikapi sebuah pendidikan, sebab wanita menjadi objek yang sering mengalami kekurangan dalam ruang lingkup pendidikan Islam, dalam karya yang disampaikan oleh Qasim Amin dengan judul Thrir al Mar'ah atau Emansipasi Wanita, menurutnya Wanita adalah objek yang menjadikan umat Islam mengalami kemunduran, hal ini melihat dari beberapa banyak wanita Mesir yang mengalami penurunan dalam segi kehidupan sosial. Karena juga di Mesir mengalami kemunduran pada kaum wanita yang tidak mendapatkan pendidikan sekolah sebab itu wanita di sana hanya mengatur masalah rumah tangga saja.Ini juga melihat pada Zaman dahulu yang menganggap wanita sebagai manusia yang sering dianggap lemah oleh sebagian manusia lainnya. Hal ini yang membuat Qasim Amin ingin merubah mindset dari orang lain yang beranggapan bahwa wanita lemah dan ingin menjunjung tinggi wanita. Banyak Tokoh membahas mengenai feminisme namun perhatian tersebut masih ada di pemikiran Qasim Amin mengena Emansipasinya, ia membuat analisa mengenai wanita dan mengarahkan kepada kehidupan sosialnya dengan melihat hak wanita Mesir dalam aspek apapun. Dalam analisa yang dilakukanya, ia menginginkan perubahan pada wanita Mesir yang memang masih tertinggal jauh oleh perempuan Barat. Qasim menginginkan adanya perubahan dengan melihat dari segi pandang dalam artian memberikan hak wanita menjadi sama dengan pria. ${ }^{13}$

Dari pemikiranya mengenai emansipasi ini Qasim melihat bahwa perkembangan yang pesat didunia barat terletak pada ikut sertanya kaum wanita dalam masalah maupun pekerjaan yang masih ada hubunganya dengan laki-laki. Di dunia barat sebagaimana terlihat bahwa wanita mempunyai kesetaraan yang sama dengan laki-laki hal ini terlihat dari segi pendidikan yang diberikan dunia barat kepada wanita. ${ }^{14}$

Di dunia pembaharuan Islam ada beberapa Tokoh yang melakukan kajian mengenai feminisme dengan beberapa teori yang mereka andalkan sesuai kemampuanya dan bukan hanya Qasim Amin yang mana mengandalkan konsep Emansipasi nya terhadap wanita Mesir. Ada beberapa Tokoh Muslim yang menggunakan kajian mengenai Feminisme. Amina Wadud Muhsin, misalnya. la merupakan seorang pemikir feminism kelahiran Malaysia yang jenjang studinya dimulai dari Universitas Antar Bangsa dan kemudia melanjutkan Masternya di University of Michigan Amerika

13 Ibid,. 95.

${ }^{14}$ T. Philipp, "Feminism and nationalist politics in Egypt", Women in the Muslim World (1978). 
Serikat dan mendapat gelar Doktornya di Havard University. la menulis kajian mengenai wanita atau feminisme yakni pada karya bukunya yang berjudul Qur'an and Woman. Dalam buku tersebut Aminah membagi penafsiran dalam beberapa kategori, yakni tradisional, reaktif dan holistik. Dalam buku tersebut akan diarahkan mengenai pembahasan terhadap kedudukan perempuan dengan semangat egalitarianism. ${ }^{15}$

Selanjutnya, Asghar Ali Engineer, seorang doctoral dalam bidang teknik sipil namun tidak lepas mengenai kelimuan agama, sebab ilmu agama ia dapatkan dari ayahnya yang menganut Syi'ah. Asghar juga merupakan seorang yang gemar menyuarakan perhatian terhadap masalah yang ada kaitanya dengan pembebasan dalam Al-Qur'an. ${ }^{16}$ Bukunya yang berjudul The Rights of Women in Islam yang sudah diterjemahkan ke dalam bahasa Indonesia dengan judul Hak-Hak Perempuan dalam Islam (1994) merupakan buku dengan permasalahan mengenai Perempuan. ${ }^{17}$ Menurutnya bahwa dalam dunia penafsiran dengan mengkhususkan terhadap persoalan perempuan meskipun dengan banyak empati maupun pro perempuan. Namun demikian Asghar melakukan percobaan dengan berbagai alternatife tafsiran terhadap ayat AlQur'an sebagai pemecah kebuntuan yang berkaitan denan maalah perkawinan, kesaksian maupun perceraian.

Sementara, tokoh yang paling popular, Fatima Mernisi, seorang guru besar lembaga Unuversitas Muhammad V Rabat di Maroko, ia mengeluarkan buku dengan bahasan mengenai Perempuan yang berjudul The Veil and the Male Elite: A Feminist Interpretation of Women's Rights in Islam, dengan arah bahasan mengenai persoalan atas penyebab kemunduran perempuan sepeninggal Nabi. Dari bukunya ini ia juga meminta dari semua pihak agar meninjau hadits-hadits palsu yang dinilai akan menyududtkan perempuan pada posisi rendah. ${ }^{18}$ Dalam artian bahwa Marnisi ingin mengajak pembaca melakukan kajian kembali terhadap masalah yang ada kaitanya dengan perempuan.

Dari beberapa Tokoh Feminisme dan juga pemikiran Qasim amin diatas bisa dilihat bahwa Tokoh Muslim pembeharu melakukan paksaan terhadap peradaban yang mana pada saat itu wanita mngalami penurunan kemartabatan, sehingga sering menyebut bahwa wanita sebagai manusia yang lemah. Peran pemikir Muslim terhadap

\footnotetext{
${ }^{15}$ Amina Wadud, Qur 'an andWoman (New York: OxfordUniversity Press, 1999).

${ }^{16}$ Asghar Ali Engineer, Pembebasan Perempuan (Yogyakarta: LKIS, 2003).

17 M. Agus Nuryanto, Islam, Teologi Pembebasan dan Kesetaraan Gender: Studi atas Pemikiran Asghar Ali Engineer. (Yogyakarta: UII Press, 2001), 7.

18 Fatima Mernissi dan Riffat Hassan, Setara di Hadapan Allah, Alih bahasa oleh Tim LSPPA (Yogyakarta: LSPPAYayasan Prakarsa, 1996), 39.
} 
Emansipasi wanita menjadi sangat diperhitungkan pemikiranya namun juga tidak lepasa dari kritik terhadapnya.

Jika dikaitkan dengan pemikir Muslim mengenai feminism maka ada lima tipologi dalam gerakan feminism dari berbagai aspek persoalan wanita: Pertama Apologi yang mana wanita dianggap tidak sadar akan hak-haknya yang terampas oleh kaum laki-laki, dengan demikian harusnya dilakukan penyadaran terhadap kaum wanita. Kedua Reformis yang mempersoalkan bahwa yang menjadi pembeda anatara laki-laki dengan wanita yakni perbedaan ada di teks dengan interpretasinya. Dengan cara mengkritik serta mengkontruksikan penafsiran tradisional. Ketiga Transformasionis, yakni suatu pendekatan yang dilakukan secara hermeneutika terhadap ayat Al-Quran dengan membagi ayat muhkamat dan mutasabihat. Kempat Rasionalis, dalam pendekatan rasionalis maka menggunakan sikap keadilan yang mana menurutnya Allah Maha adil, Pengasih dan Penyayang, maka dari itu firmannya harus dipahami secara lurus dengan sifat-sifatnya. Kelima Rejeksionis, pendekatan ini berani dalam melakukan terobosan dalam menyikapi ayat al-Qur'an. Dari kelima tipologi pemikiran diatas bisa dibilang bahwa Qasim Amin berada pada tipologi reformis yang mana ia mampu membuat pembeda di antara budaya keras yang mengharuskan wanita berada di rumah sebab dengan beraninya ia mengemukakan persolan emansipasi di tengah budaya patriakal serta ia mampu mengrekontruksi syariat yang menimbulkan diskriminasi terhadap wanita.

\section{Pendidikan sebagai Gerakan Feminisme}

Pendidikan mempunyai peranan penting dalam mewujudkan dan mengembangkan potensi dalam diri yang kemudian dapat meningkatkan kualitas hidup seseorang. Selain itu, pendidikan juga dapat mengembangkan potensi dan menyeimbangkan aspek-aspek seseorang dalam pribadi, spiritual dan sosial. ${ }^{19}$ Upaya untuk meningkatkan kualitas kehidupan dan mengangkat martabat adalah melalui pendidikan. Pemberdayaan pendidikan ini memberikan dampak positif bagi realitas hidup dan cara pandang seseorang. Oleh karena itu, dalam melawan ketidakadilan dalam hidup, manusia membutuhkan pendidikan. Begitu juga dengan kaum perempuan, bahwa pendidikan menjadi jalan bagi perempuan untuk melawan pemarginalan dan tindak diskriminatif.

${ }^{19}$ Aisjah, "Pendidikan Perempuan Dalam Perspektif Feminisme dan Islam”, Jurnal Citra Ilmu, Vol. XIII, (April 2017): 2. 
Sedangkan feminisme diartikan sebagai gerakan perempuan yang menuntut atas kesamaan hak antara perempuan dan laki-laki. Gerakan feminisme ini sesungguhnya adalah gerakan pembebasan bagi perempuan dari rasisme dan penindasan terhadap perempuan. Gerakan ini menggabungkan doktrin persamaan hak menjadi sebuah gerakan yang terorganisasi untuk mencapai hak asasi perempuan yang mana didalamnya terdapat ideologi sosial yang bertujuan untuk menciptakan ruang gerak bebas bagi perempuan. ${ }^{20}$

Ketidakbebasan yang terjadi pada perempuan tersebut juga terjadi karena berbagai faktor. Salah satunya adalah faktor tradisi, di mana perempuan masih menempatkan laki-laki sebagai penguasa dalam masyarakat dan menjunjung maskulinisme. ${ }^{21}$ Akibatnya banyak terjadi pelecehan seksual dan memperluas jaringan prostitusi dan pornografi. Tetapi hal tersebut juga tidak dilakukan secara cuma-cuma melainkan dengan alasan ekonomi yang tidak stabil dan lain sebagainya. Oleh karena itu, laki-laki menganggap bahwa perempuan adalah makhluk lemah. ${ }^{22}$

Di samping dampak positif adanya gerakan feminisme, terdapat juga dampak negatif dari akibat dari feminisme yakni ada banyak perempuan yang menolak profesi sebagai ibu rumah tangga dan lebih memilih pekerjaan secara nyata dapat dikatakan sebagai sebuah profesi, antara lain sebagai dokter, pengusaha, dan lain sebagainya. ${ }^{23}$ Jadi dapat dikatakan bahwa feminisme modern ini sangat berpengaruh bagi perkembangan teolog perempuan. Karena feminisme modern ini berasal dari agama dan budaya non-Islam di mana kehormatan perempuan lebih diutamakan ketika perempuan masih mampu mengemban tanggung jawab. Namun ketika perempuan sudah tidak berdaya dalam arti sudah memasuki usia senja, maka kehormatan perempuan tidak perlu untuk diperjuangkan dan bahkan mengirim mereka ke panti penitipan untuk menghabiskan masa tua nya. ${ }^{24}$

1. Pendidikan Feminisme Modern

Modern ini, pendidikan feminisme menganut konsep agama dan budaya yang berasal dari non-Islam atau Barat. Gerakan feminisme di Barat lahir karena adanya pandangan bahwa perempuan bukanlah makhluk rasional dan muncul tindakantindakan diskriminatif terhadap perempuan yang dilakukan oleh kaum-kaum yang

\footnotetext{
${ }^{20}$ Humm dalam Wiyatmi, Menjadi Perempuan Terdidik (Yogyakarta: UNY Press, 2013), 44.

21 Jhon L Esposito, 'Women Right in Islam', Islamic Studies, Vol. 14, No.2 (1975): 99.

22 Sri Hariati, "Aliran Feminisme Modern dan Aliran Feminisme Menurut Islam", Jurnal Hukum Jatiswara, (2017): 149.

${ }^{23}$ Heri Junaidi and Abdul Hadi, 'Gender dan Feminisme dalam Islam', Muwazah, Vol. 2, No. 2 (2010): 245-56

24 Adele K. Ferdows, 'Women and the Islamic Revolution', International Journal of Middle East Studies, Vol.15, No.2 (1983): 54.
} 
berkuasa. Di Barat, gerakan feminisme dibagi menjadi tiga yaitu, pertama gerakan yang mengusung isu mengenai hak-hak politik dan kesetaraan dalam aspek ekonomi bagi perempuan, kedua gerakan yang mengusung isu perkawinan dan peran ibu rumah tangga serta hubungan-hubungan seksual didalamnya, ketiga gerakan yang mengusung isu-isu keberagaman perempuan.

Gerakan feminisme di Barat telah melahirkan gerakan yang beragam dan menempatkan perempuan dalam berbagai sudut pandang. Diantaranya terdapat: 1) Feminisme Liberal, merupakan gerakan feminisme yang memperjuangkan hak perempuan kelas menengah. Di mana dalam feminisme liberal ini, perempuan kelas menengah telah mengorbankan hidupnya baik dari kebebasannya dan kekuasaannya kepada suaminya. Perempuan di kelas menengah seakan kehilangan hak untuk mengembangkan kemampuan rasionalnya dengan alasan untuk memanjakan diri dan menyenangkan orang lain. ${ }^{25}$ Oleh karena itu, feminisme liberal ini didirikan dan dikembangkan dalam memenuhi hak-hak perempuan baik dalam aspek pendidikan juga persamaan dalam hak berpolitik. Selain itu, hak-hak lain seperti hukum dan hak mendapat pekerjaan serta kehidupan yang layak yang setara dengan laki-laki. 2) Feminisme Radikal, gerakan ini muncul sebagai reaksi atas fenomena seksisme di mana dominasi sosial masyarakat dipandang menurut jenis kelaminnya. Gerakan ini bertujuan untuk memberantas kekerasan seksual yang terjadi pada perempuan dan adanya jaringan pornografi. Gerakan ini beranggapan bahwa tubuh perempuan merupakan faktor utama dari adanya penindasan itu sendiri. Gerakan radikal bahkan menjangkau permasalahan sampai kepada ranah privasi. Untuk membebaskan perempuan dari seksisme adalah dengan melepaskan diri dari pembatasan tersebut dan beralih kepada lesbianisme. Dalam hal ini, gerakan feminisme radikal menunjukkan bahwa perempuan dapat hidup tanpa adanya lakilaki tetapi feminisme radikal ini terjebak dalam masalah reproduksi di mana akan sulit untuk mengembangkan keturunannya. 3) Feminisme Marxis, dalam gerakan ini perempuan dianggap sudah dalam tahap bebas. Di mana ia tidak termasuk dalam manusia yang terintegrasi dan terfragmentasi. Jadi dapat dikatakan bahwa perempuan sebagai manusia yang utuh. Namun, di sisi lain dengan kebebasan yang didapat perempuan menjadi sistem perbudakan dalam dunia kerja. ${ }^{26}$ 4) Feminisme Sosialis merupakan sebuah gerakan yang mana menggunakan analisis kelas dan gender dalam memahami penindasan perempuan. Dari hal ini dapat dilihat

${ }^{25}$ Rosemarie Putnam Tong, Feminist Thought (Bandung: Jalasutra, 2006), 18-19.

26 Ibid., 149. 
beberapa permasalahan yang terjadi seperti kemiskinan yang menjadi beban perempuan dalam menjalankan peran feminin.

Dari gerakan-gerakan feminisme tersebut, disadari perlunya perkembangan intelektual pada perempuan. Anggapan ini didapat dari gerakan feminisme radikal yang dipelopori oleh Wollstonecraft yang mana nalar merupakan suatu pembeda antara manusia dan binatang. Jadi diperlukannya pendidikan bagi semua orang tanpa memandang status, kedudukan, jenis kelamin, dan lain sebagainya. Menurut Wolstonecraft untuk mendorong kemampuan nalar dan kemampuan mengambil keputusan otonom bagi perempuan adalah melalui pendidikan. Selain itu, Mills juga mengungkapkan bahwa kemampuan laki-laki dan perempuan adalah sama. ${ }^{27}$ Sedangkan menurut gerakan feminisme marxis, perempuan yang tidak bernilai berasal dari pendidikannya yang rendah. Di sisi lain pendidikan yang tidak setara dan merata menjadikan perempuan menjadi objek rasisme dan seksisme.

2. Pendidikan Feminisme Islam

Selain pendidikan umum, dalam aspek pendidikan sendiri terdapat pendidikan Islam di mana pendidikan tersebut dilatar belakangi oleh ilmu keagamaan. Adanya pendidikan Islam dimaksudkan untuk membentuk manusia yang unggul secara intelektual, amal perbuatan, dan moral etika, di mana hal tersebut merupakan ciri-ciri insan kamil sebagai manusia yang sempurna yang telah mencapai pada kualitas hidupnya. ${ }^{28}$ Prinsip utama dalam pendidikan Islam adalah mengembangkan berpikir demokratis membentuk akhlakul karimah dengan menyesuaikan kemampuan akal peserta didik. ${ }^{29}$ Terlebih lagi dalam era modern ini, di mana pendidikan Islam akan menghadapi berbagai permasalahan dan dilema dalam pemikiran pendidikan yang mana hal tersebut dihadapkan pada persoalan kemanusiaan secara universal. ${ }^{30}$

Dalam Islam, wanita diberikan kedudukan tinggi dalam berbagai aspek. Salah satunya kedudukan wanita sebagai orang tua. Pada dasarnya sudah menjadi kodrat wanita yang melahirkan anak-anaknya, namun yang membedakan adalah proses mendidiknya. Wanita merupakan madrasah pertama bagi anak-anaknya kelak, hal tersebut berlangsung hingga ia dewasa dan dapat menentukan jalan hidupnya

\footnotetext{
27 Ibid., 28.

28 Syahminan, "Modernisasi Sistem Pendidikan Islam di Indonesia Pada Abad 21", Jurnal Ilmiah Peuradeun International Muktidisciplinary Journal, Vol.II No.02 (Mei 2014): 239.

${ }^{29}$ Muhammad Athiyah al-Abrasyi, Dasar-Dasar Pokok Pendidikan Islam (Jakarta: Bulan Bintang, 1970), 165.

30 Muslih Lisa dan Aden Wijzan AZ, Pendidikan Islam dalam Peradaban Industrial (Yogyakarta: Aditya Media, 1994), 97.
} 
sendiri, tetapi tetap peran ibu dan ayah sebagai orang tua juga penting dalam pendampingan dan memberikan nasehat-nasehat. Selain itu, wanita diharuskan cakap dalam mengambil langkah yang akan dihadapi dalam perubahan ditengah masyarakat. Melihat hal tersebut, pendidikan bagi wanita sangat ditekankan. Penekanan Islam terhadap pendidikan bagi wanita bertujuan agar wanita mendapat kedudukan yang terhormat dan sederajat dengan laki-laki. Hal tersebut berkaca dari pengalaman masa lalu di masa periode Nabi Muhammad SAW di mana perempuan dianggap sebagai musibah karena dapat menimbulkan kebencian dan peperangan sesama saudara. ${ }^{31}$

Pada masa Nabi, wanita dianggap sebagai pajangan yang hanya digunakan ketika butuh bahkan keberadaan wanita diminimalisir sedemikian mungkin. Ruang gerak yang terbatas menjadikan wanita tidak mendapatkan tempat dalam mengekspresikan dan mengaktualisasikan diri. Wanita pada masa itu hanya yang dari kalangan atas sajalah yang diperlakukan secara istimewa. Selain dari itu, wanita tidak memiliki kendali apapun begitu juga dengan diri dan hidupnya. Keterbatasan wanita untuk mendapatkan posisi di ruang terbuka ini karena memang pada dasarnya dalam kultur masyarakat Arab tidak memberikan keluasan bagi wanita.

Dalam menanggapi hal tersebut, Islam sebagai agama bagi seluruh umat memberikan hak, wewenang dan kewajiban kepada wanita. Hal tersebut dilakukan atas dasar kepercayaan terhadap kapabilitas dan kompetensi wanita yang sama dengan kaum laki-laki dalam segala aspek termasuk halnya dalam aspek agama. Otonomisasi dengan kata lain adalah hak, wewenang dan kewajiban tersebut dapat menjadikan wanita menduduki posisi yang sederajat dengan kaum laki-laki. Wanita pada masa Nabi SAW dilibatkan dalam pengembangan teks pada masa itu yang melahirkan sosok wanita yang dijadikan panutan bagi wanita di dalam Islam seperti Aisyah istri Nabi SAW. ${ }^{32}$ Selain terlibat dalam pengembangan teks, wanita pada masa itu juga berpartisipasi dalam seluruh kegiatan kebudayaan yang berdampingan dengan kaum laki-laki bahkan berlomba dalam mendapatkan penghargaan. Kaum wanita juga berkesempatan mempelajari berbagai cabang ilmu pengetahuan untuk lebih mengekspresikan gagasan-gagasannya.

\footnotetext{
31 Nelsi Arisandy, "Pendidikan Dan Karir Perempuan Dalam Perspektif Islam”, Jurnal Marwah, Vol.XV No.2 ( Desember 2016): 128.

32 Leila Ahmed, Women and Gender in Islam, Historical Roots of a Modern Debate (London: Yale University Press, 1992), 99.
} 


\section{Evaluasi Pemikiran Qasim Amin}

Jika melihat pada pemikiran Qasim Amin mengenai emansipasinya, bahwa ia menginginkan akan kemerdaan kaum Perempuan yang saat itu terpuruk. la pun juga melihat bahwa harusnya perempuan juga memiliki daya saing dalam bidang pendidikan, sehingga bisa setara dengan laki-laki dalam segi kehidupan sosial. Untuk melihat bahwa pemikiranya mengenai perempuan pada saat itu maka akan saya kaitkan dengan perempuan pada dunia modern saat ini. Yang mana perempuan menjadi daya saing dari kaum laki-laki, sehingga sering djumpai banyak perempuan yang masuk di departemen pemerintahan maupun akademisi pendidikan. Hal ini bertolak balik dari pemikiran Qasim Amin yang ada dalam bukunya tentang emansipasi wanita. Saat ini perempuan sudah menjadi bagian dari kehidupan sosial, perempuan sudah tidak dianggap sebagai budak yang hanya menjadi pemuas nafsu saja, melainkan juga bisa setara dengan kaum laki-laki. ${ }^{33}$

Jika dinilai dari pemikiranya mengenai emansipasi, maka kami melihat dalam wanita dahulu yang menurut Qasim tidak sesuai dengan martabat seorang perempuan, yang jika dibanding saat ini dapat ditarik kesumpulan bahwa perempuan sudah banyak berlaga dalam dunia pendidikan maupun kehidupan sosial dengan kaum laki-laki, hal ini dapat dilihat dari sosial dan pendidikan di sekitar lingkungan. ${ }^{34}$

Wanita dianggap sebagai “pajangan” yang hanya digunakan ketika butuh, tentu pernyataan diatas merupakan bukti dari eksistensi wanita. Pemikiran seperti ini pada mulanya juga berangkat dari hal yang sama yaitu keadaan kaum wanita yang memperihatinkan. Sebelum wanita mendapatkan kebebasannya seperti sekarang ini, keberadaan wanita diminimalisir sedemikian mungkin. Ruang gerak yang terbatas menjadikan wanita tidak mendapatkan tempat dalam mengekspresikan dan mengaktualisasikan diri. Wanita pada masa itu hanya yang dari kalangan atas sajalah yang diperlakukan secara istimewa. Di sisi lain, wanita tidak memiliki kendali apapun begitu juga dengan diri dan hidupnya. Keterbatasan wanita untuk mendapatkan posisi di ruang terbuka ini karena memang pada dasarnya dalam kultur masyarakat Arab tidak memberikan keluasan bagi wanita. ${ }^{35}$

Selain itu, dalam dunia kerja perempuan lebih mendominasi daripada laki-laki sebagai penanggung jawab dalam kehidupan keluarganya. Banyak terdapat di pabrik-

\footnotetext{
${ }^{33}$ Qasim Amin, Tahrir al-mar'ah (Kairo: Dal Al-Ma'arif, 1899).

${ }^{34}$ Ibid.

${ }^{35}$ M. Zikwan, “Emansipasi wanita menurut Qasim Amin”, Media Akademika, Vol.26, No.4 (2011).. 
pabrik perusahaan yang mana kuota pekerja perempuan lebih banyak ketimbang lakilaki. Akibatnya kedudukan laki-laki menjadi tergeser tergantikan oleh perempuan yang kemudian menjadikan ia pengangguran. Terlebih lagi, laki-laki juga mengeluhkan sulitnya mencari pekerjaan yang sesuai dengan kemampuannya karena sudah tergantikan oleh kualitas perempuan. Hal ini membuktikan bahwa emansipasi wanita sudah jauh lebih merdeka dari zaman dulu bahkan kedudukan perempuan sudah mengalahkan laki-laki dalam berbagai aspek. Perempuan saat ini bukan menganggap laki-laki sebagai seorang yang bertanggung jawab tetapi seorang pesaing dalam memperoleh kehidupan yang layak. ${ }^{36}$ Dari permasalahan inilah, yang semula prinsip utama adanya feminisme dan emansipasi wanita adalah memperbaiki taraf hidup dan kesamaan hak wanita dan laki-laki. Menjadi kebebasan hak penuh terhadap perempuan tanpa ada batas.

Dalam konteks modern ini, emansipasi wanita dalam pandangan Qasim Amin, tidak terlepas dari perjuangan para wanita terdahulu yang berpengaruh dalam kesadaran religiusitas dan nilai-nilai keislaman, sehingga kehormatan wanita tetap terjaga. Namun, meskipun demikian emansipasi sendiri hanya ditelan mentah-mentah oleh wanita secara keseluruhan. Konsep feminisme dalam gerakan emansipasi wanita yang berasal dari Barat juga diterapkan tanpa adanya seleksi menurut pandangan etika keislaman. ${ }^{37}$

Gerakan emansipasi wanita pada zaman modern ini perlu diadakannya revitalisasi yang sesuai dengan nilai keislaman. Dengan begitu semangat memperjuangkan emansipasi wanita tetap terjaga namun sesuai dengan ajaran Islam. Disamping itu juga pendidikan Islam modern tetap berjalan sesuai dengan prinsip utama pembentukan pendidikan Islam sendiri. Tidak hanya itu, bahwa dogma mengenai ajaran Islam akan selalu dianggap sebagai suatu hal yang sakral yang kemudian membangun kesadaran akan pentingnya pendidikan yang didasari agama Islam dan menyemeratakan perbedaan dalam konteks peranan wanita dan laki-laki dalam berbagai aspek. ${ }^{38}$

\footnotetext{
36 T. Philipp, "Feminism and nationalist politics in Egypt", Women in the Muslim World (1978).

37 Jika dilihat dari proses pembaharuannya ini, Qasim Amin lebih cenderung untuk menggunakan pendekatan kultural daripada pendekatan struktural dalam rangka mewujudkan pikiran pikiran pembaharuannya untuk mencerahkan kehidupan bangsanya, khususnya kaum wanita di Mesir. Adapun indikasinya, adalah dengan dipentingkannya pemberian pendidikan terhadap kaum wanita dalam rangka pemberdayaan kaum wanita tersebut, yang tentu saja tidak bisa dipisahkan dengan pemberdayaan masyarakat secara umum dan ini dimaksudkannya sebagai jalan menuju cita-cita pembaharuannya. Baca, Qasim Amin, Tahrir al-mar'ah (Kairo: Dal Al-Ma'arif, 1899).

38 Zainal Abidin, "Kesetaraan Gender dan Emansipasi Perempuan Dalam Pendidikan Islam”, Jurnal Tarbawiyah, Vol. 12 No.01 (Januari-Maret 2015): 13.
} 
Sebagai bentuk kepedulian terhadap masalah wanita inilah, Qasim Amin menggagas sebuah pemikiran yang akan menjunjung martabat wanita. Wanita menjadi objek penting dalam pemikiran Qasim Amin yang menginginkan kesetaraan antara wanita dengan pria menajadi sama dalam hal kehidupan sosial maupun pendidikan. Dalam ide gagasannya mengenai emansipasi wanita jika dipahami maka tidak lebih sebagai perwujudan akan pedulinya kesadaran intelektual dari Qasim Amin terhadap kondisi wanita Mesir saat itu. ${ }^{39}$ Qasim juga menjadikan objek wanita sebagai bentuk ide emansipasinya dengan menggunakan prinsip multiplekritik terhadap dirinya. Gagasan dan pengalaman yang pada akhirnya menyadarkan Qasim bahwa telah terjadinya suatu kesalahan tentang hakikat keberadaan wanita inilah yang menjadi alasan dari gagasan pemikirannya. ${ }^{40}$ Oleh sebab itu, pendidikan merupakan satu-satunya alat untuk membebaskan diri dari terbelenggunya hak-hak asasi wanita. Menghindarkan wanita dari praktek-praktek pemarginalan dan pensubordinasian yang seakan melangkahi jalan wanita.

\section{E. Kesimpulan}

Pada bagian ini penulis menyimpulkan bahwa pengalaman Qasim Amin dan realitas sosial tentang terjadinya suatu kesalahan tentang hakikat keberadaan wanita menjadi alasan dari gagasan pemikirannya. Menurut Qasim, pendidikan merupakan satu-satunya alat untuk membebaskan diri dari terbelenggunya hak-hak asasi wanita. Menghindarkan wanita dari praktek-praktek pemarginalan dan pensubordinasian terhadap wanita. Selain hak asasi, pendidikan pada wanita juga sebagai jaminan dalam beragama seperti dalam hal beban hukum, kewajiban, dan adab. Di samping itu, wanita yang berpendidikan juga mampu untuk melahirkan anak-anak yang berkompeten untuk membangun suatu bangsa dan memajukan negaranya. Kemunculan wanita dalam ruang publik yang berprofesi sebagai pejabat pemerintahan, pegawai kantoran, reporter, bahkan politisi menjadi bukti bahwa wanita kini dianggap sudah mendapatkan kebebasannya sebagai bentuk kesadaran gender di mana kedudukan antara laki-laki dan wanita adalah sama. Kebebasan inilah yang disebut dengan emansipasi wanita yang mana kebebasan wanita sangat dijunjung tinggi. Wanita bebas mendapatkan haknya untuk tampil dan mengutarakan pendapatnya tentang apa yang ia cari. Emansipasi wanita ini merupakan proses wanita untuk melepaskan diri dari kedudukan sosial yang rendah dan pengekangan hukum yang membatasi perkembangan dan kemajuan wanita.

\footnotetext{
${ }^{39}$ Siregar, Pemikiran Qasim Amin Tentang Emansipasi Wanita, 257.

40 Qasim Amin, Tahrir al-mar'ah (Kairo: Dal Al-Ma'arif, 1899). 


\section{F. Referensi}

Abidin, Zainal. "Kesetaraan Gender dan Emansipasi Perempuan Dalam Pendidikan Islam”. Jurnal Tarbawiyah, Vol. 12 No.01 (Januari-Maret 2015): 13.

Abrasyi (al), Muhammad Athiyah. Dasar-Dasar Pokok Pendidikan Islam. Jakarta: Bulan Bintang, 1970.

Ahmed, Leila. Women and Gender in Islam, Historical Roots of a Modern Debate. London: Yale University Press, 1992.

Aisjah. "Pendidikan Perempuan Dalam Perspektif Feminisme dan Islam”. Jurnal Citra IImu, Vol. XIII, (April 2017): 2.

Amin, Qasim. Tahrir al-mar'ah. Kairo: Dal Al-Ma'arif, 1899.

Arisandy, Nelsi. “Pendidikan Dan Karir Perempuan Dalam Perspektif Islam”. Jurnal Marwah, Vol.XV No.2 ( Desember 2016): 128.

Buthi (al), Sa'id Ramadhan. Fiqh al-Sîrah. Damascus: Dar al-Fikr, 2008.

Engineer, Asghar Ali. Pembebasan Perempuan. Yogyakarta: LKIS, 2003.

Erasiah, E. "Tokoh emansipasi wanita Islam di Mesir pada abad ke 19 M". Kafaah: Journal of Gender Studies, Vol.4 No.2 (2014): 202-218.

Esposito, Jhon L. 'Women Right in Islam', Islamic Studies, Vol. 14, No.2 (1975): 99.

Ferdows, Adele K. 'Women and the Islamic Revolution'. International Journal of Middle East Studies, Vol.15, No.2 (1983): 54.

Handayani, Chrisna S., dan Novianto, Ardhian. Kuasa Wanita Jawa. Yogyakarta: LKiS, 2004.

Hariati, Sri. “Aliran Feminisme Modern dan Aliran Feminisme Menurut Islam”. Jurnal Hukum Jatiswara, (2017): 149.

Hazm, Ibn. Jawâmi’ Sîrah Nabawiyyah. Beirut: Dar al-Kutub, t.t.

Junaidi, Heri., and Hadi, Abdul. 'Gender dan Feminisme dalam Islam'. Muwazah, Vol. 2, No. 2 (2010): 245-56

Lisa, Muslih., dan AZ, Aden Wijzan. Pendidikan Islam dalam Peradaban Industrial. Yogyakarta: Aditya Media, 1994. 
Masruroh. "Pemikiran Qasim Amin Tentang Hijab”, Jurnal Keislaman, Kemasyarakatan dan Kebudayaan, Vol. 18 No.1 (2017): 94.

Mernissi, Fatima., dan Hassan, Riffat. Setara di Hadapan Allah, Alih bahasa oleh Tim LSPPA. Yogyakarta: LSPPA-Yayasan Prakarsa, 1996.

Mulia, Siti Musdah. Muslimah Reformis: Perempuan Pembaru Keagamaan. Bandung: Mizan Pustaka, 2005.

Nasution, Harun. Pembaharuab dalam Islam, Sejarah Pemikiran dan Gerakan. Jakarta: Bulan Bintang, 1975.

Nuryanto, M. Agus. Islam, Teologi Pembebasan dan Kesetaraan Gender: Studi atas Pemikiran Asghar Ali Engineer. Yogyakarta: UII Press, 2001.

Philipp, T. "Feminism and nationalist politics in Egypt", Women in the Muslim World (1978).

Schirrmacher, Christine. Islam and Society, ed. by Geoff Tunnicliffe. Bonn: Verlag für Kultur und Wissenschaft, 2008.

Shabuni, Muhammad Ali, Shafwah al-Tafâsîr, Jilid 3. Kairo: Darus Shabuni: 2009.

Shalih, Su'ad Ibrahim. "Kedudukan Perempuan dalam Islam”, dalam Mohammad Atho Mudzhar dkk. Perempuan" dalam Masyarakat Indonesia: Akses, Pemberdayaan dan Kesempatan. Yogyakarta: Sunan Kalijaga Press, 2001.

Siregar, Eliana. “Pemikiran Qasim Amin Tentang Emansipasi Wanita”. Jurnal Ilmiah Kajian Gender, Vol.VI No. 2 (2016).

Syahminan. "Modernisasi Sistem Pendidikan Islam di Indonesia Pada Abad 21". Jurnal Ilmiah Peuradeun International Muktidisciplinary Journal, Vol.Il No.02 (Mei 2014): 239.

Tong, Rosemarie Putnam. Feminist Thought. Bandung: Jalasutra, 2006.

Wadud, Amina. Qur 'an andWoman. New York: OxfordUniversity Press, 1999.

Wiyatmi. Menjadi Perempuan Terdidik. Yogyakarta: UNY Press, 2013.

Zikwan, M. "Emansipasi wanita menurut Qasim Amin". Media Akademika, Vol.26, No.4 (2011). 